\title{
Improving Financial Planning Graduate Employability Through Enterprise Education
}

John Teale, University of the Sunshine Coast ${ }^{1}$

\begin{abstract}
Financial planning requires students to display tacit learning. However, the traditional teaching approach concentrates on theory development independent of any applied connection with the profession.

This paper uses an adaptation of the Goetz et al. (2005) model to demonstrate how curricula can provide a smoother progression into the financial planning profession. Further, a number of teaching strategies are described to provide a closer connection with the profession.
\end{abstract}

Keywords: financial planning education; curriculum reform; financial planning; higher education

JEL Classification: I20; J24; D14

\footnotetext{
${ }^{1}$ jteale@usc.edu.au
} 


\section{Introduction}

By combining the explicit knowledge with practical experience students' employability is improved as well as their transition into the profession. Employability is important to students because it "makes a person more likely to choose and secure occupations in which they can be satisfied and successful" (Pool \& Sewell, 2007). Employability is also of prime importance for universities as it develops a perception of relevance to academic study (Rae, 2007). This paper discusses changes to financial planning curricula that develops employability skills and eases the transition of students into the profession. Further, it discusses the use of various approaches to teaching that involves the use of experiential learning combined with work-integrated learning as pedagogy. These techniques are capable of bringing the profession into the classroom and so enable students to acquire the skills required by employers.

The Goetz et al. (2005) model contains a number of self-reported teaching techniques used by several universities in the United States as part of their Certified Financial Planning Board-Registered programs. The authors include several other techniques that they suggest could be used to enhance financial planning education. This paper discusses a number of these teaching techniques as they are currently being used in Australian financial planning education and where evidence could be found of their use. It excludes others because of perceived legislative restrictions on providing financial advice without being licensed to do so and possible university policy restrictions and liability issues.

This paper is important because the subdued economic climate has resulted in an oversupply of financial planners (Barbaro, 2012), which means that graduating financial planning students will find it difficult to gain employment if they are not well qualified and can show some experience in the profession.

This paper will be the first to propose an employability model that eases Australian financial planning students' transition from academia to their profession. It will also add to the understanding of the use of experiential learning as educational pedagogy in financial planning education in Australia.

This paper first defines employability and examines the background literature relevant to the development of the competencies required by financial planning students. Further, experiential and work integrated learning (WIL) theory will be discussed, along with their role in producing competent students.

\subsection{LITERATURE REVIEW}

\subsection{Employability}

In order to prepare students for the workplace it is necessary for them to have well developed specific explicit and tacit skills that will be useful to employers (Rainsbury et al., 2002). In 2001, the Australian Chamber of Commerce and Industry and the Business Council of Australia undertook a major research project designed to provide the Department of Education, Science and Training (DEST) with a detailed understanding of the employability skills needs of industry. The research was published by the Commonwealth of Australia in 2002 as the report Employability Skills for the Future.

In the report the generic employability attributes, or skills are identified as "communication, teamwork, problem solving, initiative and enterprise, planning and organisation, self-management, learning and technology” (DEST 2002, p.54). Therefore, employability refers to: 
Obtaining a set of cognitive and behavioural competencies that an individual must gain in order to be a competent financial planner and which contribute to the strategic objectives of the practice.

Competency can be viewed as a set of explicit or codified learning that improves an individual's ability to perform a specific task (Birkett, 1996). These explicit skills (knowing what) in turn improve the rate of learning of tacit skills (know-how) that are gained by experience: that is, competency is realised in performance (Birkett, 1996). Therefore, possessing skills is a precursor to competency (Rudman, 1995).

Explicit and some tacit knowledge and skills are gained from the cumulative learning experience of university financial planning education, but these must be combined with a range of "formative experiences and wider contextual learning through, for example, work experience and extra-curricular activities" (Rae, 2007, p608) in order to be considered competent. That is, competency is a product of the entire university and work experience.

\subsection{Achieving financial planning competency}

Financial planning, like accounting, medicine and law, is an applied profession (Houterman 2009), that is, a profession that applies business theories to real world situations (Investopedia, 2012). It requires the possession of and ability to apply a wide array of skills ranging from psychology, communication counselling, leadership, motivation and marketing (Goetz et al., 2005). It also involves skills involving negotiation, analysis and synthesis of information (Financial Planning Standards board, 2007). Being able to apply learned skills in the workplace is an ability that employers are seeking (DEST, 2004). Therefore, the skills that the students have gained during their tertiary education must be transferable to the workplace.

Universities are good at implanting technical skills by providing a strong knowledge base, but tend to produce students “... without the ability to intelligently apply that knowledge in the work setting" (Precision Consultancy 2007, p2). Therefore, the concept of 'employability' suggests that students should be given a holistic learning experience that combines structured learning, with industry participation, work experience and extracurricular activities (Jackling \& Sullivan, 2007).

This paper argues that these competencies can be developed by applying active learning enterprise education. The primary focus of the enterprise pedagogy is to develop students' "personal skills, abilities and attributes" (Jones \& Iredale, 2010). Jones and Iredale (2010) further argue that the goals of enterprise pedagogy are achieved by utilising experiential education. The Association for Experiential Education (2011) defines experiential education as:

“...a philosophy and methodology, in which educators purposefully engage in direct experience and focused reflection in order to increase knowledge, develop skills and clarify values".

Traditional tertiary learning focuses on conceptual knowledge by organising material so that students build theoretical knowledge by attending lectures, tutorials and conducting private research as part of their assignments, but with limited practical application (Rossetto \& Murphy, 2010). This learning method treats learning like a product and while it will produce capable students it is unlikely, on its own, to produce competent students.

Kolb (1984) identifies three learning stages in experiential learning; the first stage involves the 'acquisition' of basic skills; the second involves transitioning students into the 'specialised' areas that they will require in their future practice; and finally, the students' 'integration' phase during which they analyse and synthesise their knowledge and skills. There are significant advantages for financial planning educators in using this type of 
knowledge accumulation (Goetz et al., 2005) such as, combining 'hard' (cognitive knowledge) and 'soft' (behavioural) skills through targeted real life activities, that combine 'knowing' and 'doing'. In this way, students are able to apply their knowledge to a variety of situations, and reflect on their experiences to determine any weaknesses they need to address and strengths they have gained.

Experiential learning is an ideal pedagogy particularly when used in conjunction with WIL (Patton \& McMahon, 2001; Final Project Report, 2009). WIL is defined as "an umbrella term for a range of approaches and strategies that integrate theory with the practice of work within a purposefully designed curriculum" (Patrick et al., 2009, piv), that is, students learn through experience. Kolb (1984, p38) emphasised the importance of learning through experience when he defined learning as "a process whereby knowledge is created through the transformation of experience" leading to preferred lifelong learning outcomes. Therefore, career development learning is a continuous process which is grounded in experience (Final Project Report, 2009), critical reflection (Ebrall et al., 2008), and formative feedback (van Rensburg \& Danaher, 2009, Nicol \& McFarlane-Dick, 2006).

The transformation of experience can be achieved by developing education programs "that combine and integrate learning and its workplace application, regardless of whether this integration occurs in industry or whether it is real or simulated" (Atchison et al. 2002, p3). WIL is a powerful tool when used in the development of generic or professional skills (Freudenberg et al., 2011) and provides an additional benefit by giving students the opportunity to improve their work readiness and employability (Knight, 2007). WIL assists students in transferring their class room learning to the workplace and there is evidence that students who complete work placements are able to successfully apply their generic skills in the workplace (Crebert et al., 2004; Freudenberg et al., 2011).

A number of research articles appear in the business literature testifying to the effectiveness of WIL: building career skills (Freudenberg et al., 2009), enhancing selfefficacy through a work integrated learning program (Subramaniam \& Freudenberg, 2007), engaging students in WIL (Bandaranaike \& Willison, 2011, and finally, WIL and generic skill development (Freudenberg et al., 2011).

The core objective of WIL programs is to develop students' abilities, "transfer theory to practice, to develop generic skills and improve graduate employability" (von Treuer et al., 2011, p197). However, WIL does pose some challenges. The WIL Report (2009) identifies a number of resourcing issues. These include: they are expensive to maintain, are a time consuming experience, impose a heavy workload on academics, and it is becoming increasingly difficult to find placements. Employers find considerable time is involved and that they incur some expense when fixing mistakes and placements are difficult. Students find that in many cases it is difficult to balance part-time work, placements and study.

\subsection{Employability model}

The employability model in figure 1 illustrates how the merging of university with the profession can provide a smoother transition into the workplace.

The model proposes that the university and the profession must be more closely integrated in order for financial planning students to graduate as fully competent and in so doing become an employee of choice. The remainder of this paper will discuss a number of techniques that will assist in closing the gap between students' university studies and the professional workplace. 
Figure 1: Integrating academic education with the profession

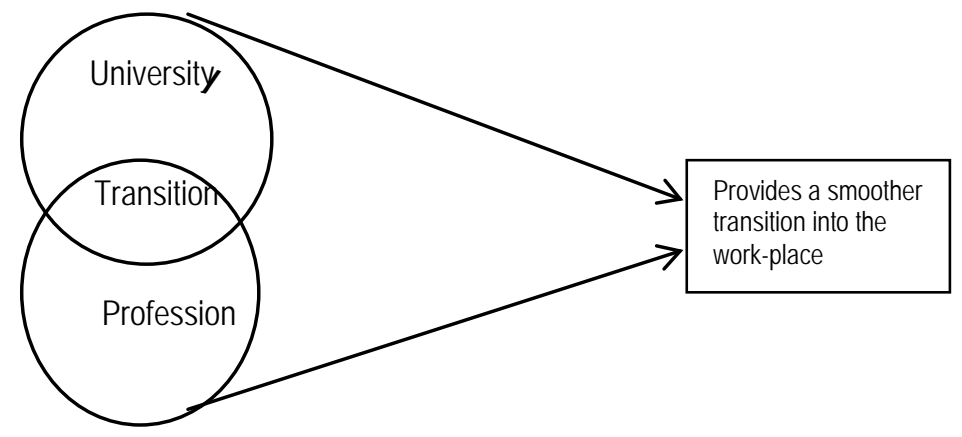

Source: Adapted from Goetz et al., (2005)

This paper argues that the gap that exists for many students between their university education and entering the workforce can be closed by adopting holistic teaching methods to develop students' employability skills and by developing closer involvement with the industry through cooperative education programs (Precision Consultancy, 2007). There has been a recognition in higher education that the teaching of tacit skills are as important as explicit skill content (Cooper, 2005).

Academics should adopt experiential education combined with WIL to address this challenge of skill development and to assist students in gaining employability skills. Several WIL techniques listed in table 1 are being used in Australian universities' business schools to achieve this goal and will be discussed in turn.

\section{Table 1: Techniques that allow application of knowledge}

\subsubsection{Internships}

3.1.2 Mentoring relationships with professionals

3.1.3 Gaining extra certifications

3.1.4 Student participation in the professional body

3.1.5 Participation of lecturers in the professional body

3.1.6 Part-time jobs in financial planning

3.1.7 Use of financial planning software

3.1.8 Guest speakers

3.1.9 Inclusion of a capstone course

3.1.10 Employability skills portfolio

\subsubsection{Internships}

Internships are a structured, student-centred, integrated curriculum-based educational experience utilising practical applications and active involvement that extends beyond the traditional classroom setting (Beard, 2007). Furthermore, internships are able to be aligned with the processes and outcomes of experiential learning (Kolb, 1984). Internships combine workplace experience with formal learning and are an ideal method of teaching students how to transfer theory to the workplace, giving students the opportunity to study alongside work 
and to move between study and work (Thornton \& King, 2006).

Structured internships allow students to learn specific job skills (Garavan \& Murphy, 2001). Page et al. (1999) list these skills as critical thinking, resilience to the pressures of professional work, gaining a perceived edge in the job market, improved communication skills, learning to work in teams, learning about politics in the workplace, and the application of classroom learning. Furthermore, internships also aid in the development of generic skills (or, employability skills) (Freudenberg et al., 2011) that includes communication, teamwork, initiative, work value and ethics (Precision Consultancy, 2007).

The development of ethical attitudes and skills is of particular importance since the introduction of the 'best interest duty' for financial planners, which requires planners to act in the best interest of their clients contained in the federal Government's Future of Financial Advice reforms. The requirement of adhering to a high ethical standard is also a requirement of the Financial Planning Association's (FPA) Code of Ethics.

A search of the literature reveals limited evidence of the successful use of internship placement in the financial planning sector. These include the development of personal financial planning students' client relationship skills (Eyssell, 1999) and the development of business students' generic skills (Freudenberg et al., 2011). However, universities face challenges in the implementation of these programs within financial planning degrees.

These challengers include limitations on the availability of placements within the financial planning sector (Final Project Report, 2009), the lack of motivation by students to gain employability skills (Rae, 2007), and on the commitment of universities to provide sufficient funding and support to ensure the success of these programs (Brimble \& Freudenberg, 2010). In short, internships are an "effective way for students to gain practical experience and be prepared to transition into the workplace” (Goetz et al., 2005). Students support this statement by indicating that they place great value on the internship experience, particularly when internship has a direct connection with their career goals (Hergert, 2009).

\subsubsection{Mentoring relationships with professionals}

Students transitioning from university to the workforce have traditionally been seen as an inevitable, but sometimes problematic step (Holden \& Hamblett, 2007). In order to smooth this step for students many universities are offering structured mentoring programs to help them build knowledge about their intended profession and develop relationships that will help them after graduation (Precision Consultancy, 2007).

Mentoring is defined as a "nurturing process in which a more skilled or experienced person, serving as a role model, teaches, sponsors, encourages, counsels and befriends a less skilled or less experienced person for the purpose of promoting the latter's professional and/or personal development” (Anderson \& Shannon, 1988, p40). While a mentor is a person with advanced experience, knowledge, wisdom, skills and influence (D’Abate \& Eddy, 2008) "who takes a special interest in the professional and personal development of another" (Dawson \& Watson, 2007, p4) through an interactive relationship. In addition, mentors act as career coaches and provide students with valuable learning experiences (Goetz et al., 2005).

The mentoring experience gives students insights into the 'real-world' practicalities of managers' roles, their organisations, and industries (Gannon \& Maher, 2011). It also increases their awareness of how their education program is building the generic skills that they will be using in their professional careers (Precision Consultancy, 2007) and improves reflective learning and networking (Goetz et al., 2005). Furthermore, mentoring enhances 
student employability and facilitates insights into professional work (Gannon \& Maher, 2011).

However, mentoring programs do experience some difficulties. Gritch (2006) reports participant enthusiasm often decreases during the program because mentors are generally well established and successful practitioners who experience difficulties in devoting sufficient time to the program such as accountants during tax season. Mentees experience time difficulties when assignments need to be completed. There also can be problems arising with the selection of inappropriate mentors who are not screened adequately during the selection process.

A number of different models are used in mentoring programs. They can be either informal or formal. In an informal program the mentor and mentee find each other while a formal program contains minimum standards. These involve an interview with the student, a written assignment and a minimum number of meetings (Schlee, 2000). The differences in other models have been documented by Jacobi (1991) and include the following: in some programs the mentors are trained while in others they are not. Some programs assign mentors to the mentees while in other programs the mentee selects the mentor. Some programs designate the location and frequency of meetings, while others leave it to the participants to decide. In addition, some programs are evaluated while others are not or are evaluated using vague and imprecise techniques.

There are also a number of additional models which are listed in the Final Project Report (2009). These include: one to one relationships, participation in small groups, face to face or via the web. Mentoring can also occur 'on part of work placements, internships or practicums' (p43). The utilisation of mentoring programs is being increasingly used by universities worldwide as there is a recognition that academics may need external assistance and insights to equip students with the required graduate attributes demanded by employers (Gannon \& Maher, 2011).

Australia universities are increasingly implementing mentoring programs to expose students to experienced professionals with the aim of assisting them 'to reflect on their development needs and career direction' (Precision Consultancy, 2007, p33). A search of university web sites revealed only one mentoring program involving financial planning students. This program is the Griffith Industry Mentoring Program that commenced in 1994 and involves approximately 200 business and financial planning students drawn from five University campuses. Its objectives are 'to assist students' transition from study to graduate work by facilitating in-depth understanding of potential employing organisations, work roles and workplaces relevant to their degrees'. These objectives can be viewed at http://www.griffith.edu.au/careers-employment/industry-mentoring-program.

\subsubsection{Gaining extra certifications}

Although there are limited opportunities for students to obtain industry certifications during their studies it is possible for them to gain such a qualification in tax advice. Under the Future of Financial Advice reforms, financial planners will be required to be registered with the Tax Agents Board if they wish to include tax advice as part of providing advice on financial products.

Tax studies are generally included in a financial planning degree, and if covered in sufficient depth, students may be able to qualify for certification, thereby increasing their technical skills and employability chances by reducing training and certification costs for employers in step three of the traditional model shown in figure 1. 


\subsubsection{Student participation in the professional body}

Belonging to a professional body and attending their meetings is an important part of career development (Cottrell et al., 2009). However, most students have little knowledge about their professional body and the role it plays in professional development (Mata et al., 2010). Therefore, students should be encouraged to join and become involved in their professional body as this involvement exposes them to the working of the profession and provides opportunities to develop relationships with financial planning professionals (Goetz et al., 2005).

Involvement can also extend to nominating for positions on local or national committees. The members of these committees are generally highly successful practitioners who can act as mentors and can enhance the student's career by providing him/her with valuable networking opportunities (Mata et al., 2010). Committee membership allows the student to gain an overall understanding of the profession, being seen as standouts among their peers and provides opportunities to develop leadership, communication skills, and effective team skills (Gray, 2005).

Being an active member of the professional body provides opportunities for students to learn the importance of continuing education, how current events can affect the profession, and how developing a sense of belonging to the profession can bring opportunities for paid part-time work, internships and eventual career opportunities (Goetz et al., 2005).

The faculty is able to play an active role in encouraging financial planning students to participate in the professional body 'providing applications, organising conference travel and generally serving as role models for involvement in professional associations' (Mata et al., 2010, p451). A number of students at the University of the Sunshine Coast have joined the FPA as student members and attend seminars and report an increase in their enthusiasm to enter the profession.

\subsubsection{Participation by lecturers in the professional body}

Financial planning academics should become involved in the profession. This involvement can be either as a member of the professional body, as a committee member, as a member of a local chapter, or with consulting with local practices. Goetz et al. (2005) discuss a number of advantages of this involvement that include gaining an understanding of current issues from a practitioners point of view, maintaining current knowledge by completing continuing professional courses, being aware of new products, and providing material for assignments and class discussions.

A number of Australian financial planning academics do participate in national committees with the FPA. These academics have been instrumental in the drafting of the FPA's new accreditation procedures of the tertiary financial planning programs and the associated education requirements. These academics are associated with Victoria University, the University of Western Sydney, Griffith University, La Trobe University and the University of the Sunshine Coast.

\subsubsection{Part-time jobs in financial planning}

Part-time jobs provide an opportunity for students to apply their learned skills in the workplace. These jobs include answering the telephone, filing or gathering information from clients, and help produce productive work habits and exposure to regulatory compliance (Goetz et al., 2005). Students in the last year of their course at the University of the Sunshine Coast have been given the opportunity to assist paraplanners in the preparation of financial 
plans during their work placements. All these activities will improve students' employability skills and competence, and help ease the transition to full-time employment. Research in the United Kingdom indicates that relevant work experience during students' degree studies has a significant influence on employability (Precision Consultancy, 2007).

Universities are able to assist students in gaining part-time employment. Those universities that provide financial planning education often receive approaches from practices who are seeking full and part-time placements. Student services at the University of the Sunshine Coast send these enquiries to the financial planning lecturers and post them on the university web site. A number of students have been able to secure part-time employment by responding to these enquiries. Students report that working in a financial planning practice increases their enthusiasm as they can see the relevance of what they are being taught.

\subsubsection{Use of financial planning software}

The mission of higher education is to produce learning and not teaching (Barr \& Tagg, 1995). In keeping with this philosophy, many universities are employing a learner-centred paradigm (LCP) that encourages the integration of technology with real-world experience in the classroom (Lester \& Cole, 2009). Lester and Cole note further that this learning paradigm involves students as interactive participants in the learning experience. This experience also improves student attitudes and student performance (Weimer, 2002).

The use of computer technology as a learning vehicle is widely used in finance degrees during which students are exposed to simulated trading rooms. Evidence of its use in the US indicates that it adds to soft skill development, specifically team work, critical analysis, communication and in the development of technological skills (Lester \& Cole, 2009). In Australia software providers are forming alliances with universities to make their software available in IT courses. Hawking and McCarthy (2000) provide evidence that positive benefits emerging from the use of this software have resulted in students taking responsibility for their learning and proceeding to well-paid jobs.

Similar alliances are being developed by several Australian financial planning software providers who are sponsoring their software into financial planning programs with a number of universities. These universities include the University of the Sunshine Coast, the University of New England, Curtin University and the University of Southern Queensland. The software is used in a number of ways including product research, investment strategy development and statement of advice preparation. Using the software in this way allows lectures to utilise teaching techniques like problem based learning, simulations and real life case studies. While a search of the literature does not reveal any empirical research into the outcomes of the usage of financial planning software in tertiary education, it would be expected to produce similar outcomes to that observed in IT and finances courses.

\subsubsection{Guest speakers}

Involving guest speakers in the classroom brings many benefits. These include: adding diversity and presentation of the real-world to students (Zorek et al., 2011), conveying their experiences in ways that are appreciated by students and how they could be applied in the real world (Schmidt et al., 2008). The guest speakers often act as role models for students (Phillips \& Phillips, 2002), by providing specialist knowledge and skills based on practical experiences, and by stimulating discussion on current issues and promoting new ways of thinking (Hogan, 2009).

In addition, Smith (2001) reports that external speakers are an effective way to show that the topics being taught are important and emphasise that the ability to learn is essential 
for to-day's professionals. Finally, Goetz et al., (2005, p242) state that when financial planning professionals are used as guest speakers "students hang on a professional's every word”.

Guest speakers are also used as an experiential learning technique by demonstrating their activities (Paul \& Mukhopadhyay 2005). These techniques encourage two-way discussion which improves students' verbal communication skills and written communication skills when students are required to prepare a written reflective assignment about the discussion (Zorek et al., 2011).

There are a number of fringe benefits that emerge from involving professionals in the classroom. These fringe benefits include enabling students to clarify their career interests and goals (Zorek et al., 2011) and by providing networking opportunities and helping financial planning professionals become aware of the pool of talent that is available within the financial planning student population (Goetz et al., 2005).

The University of Western Sydney invites speakers to address their financial planning students and reports positive benefits for students. It advises that the benefits include: bringing the real-world into the classroom; giving examples of how the profession operates; and in the capstone course, guiding students through a statement of advice from a practitioner's perspective.

\subsubsection{Inclusion of a capstone course}

Capstone courses are generally offered during the final year of a student's education. Holdsworth et al., (2009) describe these courses as an opportunity for students to apply the knowledge they have gained throughout their undergraduate studies. This course "involves integrating graduate capabilities and employability skills" (p2) and consolidates and applies experiential learning.

Students are able to demonstrate their ability to apply their knowledge by the preparation and presentation of a written financial plan (or, statement of advice (SOA)). The preparation of the SOA is a problem-based learning case study (Goetz et al., 2005) that tests students' technical skills as well as their oral and communication skills (Jackling \& Sullivan, 2007).

A capstone course is a requirement of the FPA's unit CFP 5 of the Certified Financial Planner (CFP) certification program. It is also a requirement of the new FPA education standards and features in many university financial planning programs. However, Australian universities have been slow in incorporating capstone courses in their degrees (Holdsworth et al., 2009). This is the case with financial planning degrees as a search of university web sites reveal that only six of the 25 universities listed on the ASIC Financial Planning Training Register include a capstone course in their curriculum. These include University of the Sunshine Coast, Griffiths University, La Trobe University, Curtin, University of Southern Queensland, and University of New England.

\subsubsection{Employability skills portfolio}

An employability skills portfolio is a personal record of a student's accomplishments. It is also a record of a student's life and learning that reflect the student's true abilities, skills and accomplishments. This is essential as "employers value employability skills when they are used in actual employment” (ANTA 2004, p32). Therefore, students need to document the employability skills gained in university studies, work or internship placement, and during their life experiences. The outcome of this document enables the student to show that he/she has gained important employability skills, shows a prospective employer why he/she should 
be hired and enables the student to identify weaknesses in their employability skills that need to be rectified.

The final report on employability skills prepared for the Department of Education, Science and Training by the Australian National Training Authority (ANTA) identifies two important outcomes of an employability portfolio:

- employment - getting a job, keeping and advancing in a job and getting a better job; and

- Self-development - understanding your own employability skills and the need for continued development of employability skills over a working life-time” (ANTA 2004, pVII).

The ANTA (2004, p16) report on employability skills points to the global trend of moving away from input-defined 'learning about' to outcome defined 'learning how'. This change requires an evidence-based assessment approach and the use of employability skills portfolios. A search of university web sites reveals that students are assisted in developing these portfolios.

\section{Conclusion}

This paper demonstrates that the possession of theory is not the skills that employers are seeking, but the ability of graduates to apply theory to real-world work settings.

There are a number of teaching techniques that can be incorporated into financial planning curricula to enable students to gain tacit skill abilities and shorten the transition into the professional financial planning world. It is demonstrated that these techniques are being used by a number of universities in their financial planning programs and are capable of enabling students to attain both the technical and behavioural skills outlined in the Birkett model.

The techniques are based on experiential pedagogy that emphasises the application of theory. It is argued that this can be achieved by combining WIL with experiential learning. It is shown that gaining the ability to apply theory to the workplace produces competent students and these are the qualities employers are seeking.

Financial planning undergraduate students are the future financial planning professionals, and by undergraduate financial planning educational programs adopting the employability model, the transition from student to entry into the profession will be shortened. 


\section{References}

Anderson, E. \& A. Shannon. (1988). 'Toward a conceptualisation of mentoring', Journal of Teacher Education, Vol. 39, No. 1, pp38-42.

http://dx.doi.org/10.1177/002248718803900109

Association of Experiential Education (AEE) (2011), What is experiential education? Available at http://www.aee.org/about/whatIsEE. Accessed 5 October 2012.

Atchison, M., Pollock, S., Reeders, E., \& Rizzetti, J. (2002), Work-integrated paper. Melbourne, Australia: RMIT University.

Australian Chamber of Commerce and Industry and the Business Council of Australia (2002), Employability Skills for the Future, DEST, Canberra, pp2-3.

Australian National Training Authority (ANTA) (2004), Employability skills: Final Report, Department of Education, Science and Training, Canberra.

Bandaranaike, S, \& Willison, J. (2011), 'Engaging students in work integrated learning: Drives and outcomes', Proceeding on Cooperative \& Work-integrated Education, In: WACE $17^{\text {th }}$ World Conference on Cooperative \& Work-integrated Education, Philadelphia, PA, USA.

Barbaro, P. (2012), 'Job market sees oversupply of financial advisers', Money Management, 27 Sep., p6.

Barr, R.B. \& Tagg, J. (1995), 'From teaching to learning: a new paradigm for undergraduate education’, Change, Vol. 27, No. 6, pp12-25. http://dx.doi.org/10.1080/00091383.1995.10544672

Beard D.F. (2007), 'Assessment of internship experiences and accounting core competencies', Accounting Education, Vol. 5, No. 2/3, pp496-405.

Birkett, W. P. (1996), Competency standards for financial planning in Australia and New Zealand, Sydney; Financial Planning Association of Australia Ltd.

Brimble, M. \& Freudenberg, B. (2010), 'WIL WIL’ing work? B-Hert News, 28 (April), pp24.

Cooper, D. (2005), Assessing what we have taught: the challenges faced with assessment of oral presentation skills, paper from the Higher Education Research and Development Society of Australasia Conference 2005.

Cottrell, R.R., Girvan, J.T. \& McKenzie, J.F. (2009), Principles and foundations of health promotion and education ( $4^{\text {th }}$ edn), Pearson Benjamin Cummings, San Francisco, CA.

Crebert, G., Bates., Bell, B., Patrick, C.-J. \& Cragnolini, V. (2004), 'Developing generic skills at university, during work placement and in employment: graduates' perceptions', Higher Education Research \& Development, Vol. 23, No. 2, pp147-165. http://dx.doi.org/10.1080/0729436042000206636

D’Abate, C.P. \& Eddy, E.R. (2008), “Mentoring as a learning tool: enhancing the effectiveness of an undergraduate business mentoring program”, Mentoring \& Tutoring: Partnership in Learning, Vol. 16, No. 4, pp363-78. http://dx.doi.org/10.1080/13611260802433692

Dawson, G.S. \& Watson, R.T. (2007), 'Involved or committed? Similarities and differences in advising and mentoring in the academic and business world', Communications of the Association for Information Systems, Vol. 20, pp3-10.

Department of Education, Science and Training (DEST) (2002), Employability skills for the future, a report by the Australian Chamber of Commerce and Industry and the Business Council of Australia for the Department of Education, Science and Training, Canberra.

Ebrall, P., Repka, A., \& Draper, B. (2008), 'Critical reflection in work-integrated learning', in Chiropractic Journal of Australia, Vol. 38, No. 2, pp49-57. 
Eyssell, T.H. (1999), 'Learning by doing: offering a university practicum in personal financial planning', Financial Services Review, Vol. 8, Iss. 4, pp293-303. http://dx.doi.org/10.1016/S1057-0810(00)00047-0

Final Project (2009), Career Development Learning: maximising the contribution of workintegrated learning to the student experience, Australian Learning and Teaching Council.

Financial Planning Standards Board (2007), Financial Planner Competency Profile. Available at: http://www.fpsb.org/certificationandstandards/competencyprofile.html.

Freudenberg, B., Brimble, M. \& Cameron, C. (2009), 'The building of a professional: creating greater career identity within a degree', The International Journal of Learning, Vol. 16, No. 10, pp253-265.

Freudenberg, B., Brimble, M. \& Cameron, C. (2011), 'WIL and generic skill development: the development of business students' generic skills through work-integrated learning', Asia-Pacific Journal of Cooperative Education, Vol. 12, No. 2, pp79-93.

Gannon, J.M. \& Maher, A. (2011), "Developing tomorrow's talent: the case of an undergraduate mentoring programme", Education + Training, Vol. 54, Iss. 6, pp440455.

Garavan, T., \& Murphy, C. (2001), 'The co-operative education process and organisation socialization: a qualitative study of student perceptions of its effectiveness', Education + Training, vol. 43, pp281-302.

Goetz, J.W., Tombs, J.W. \& Hampton, V.L, (2005), 'Easing college students’ transition into the financial planning profession’, Financial Services Review, vol. 14, no. 3, pp231251.

Gray, R.E. (2005), 'Developing leadership skills by participating in professional organizations', The Journal of Government Financial Management, Vol. 54, No. 4, pp46-48.

Gritsch, M. (2006), 'The role of teaching, scholarly activities and service on tenure, promotion and merit pay decisions: dean's perspectives, Allied Academics International Conference, Academy of Educational Leadership, Proceedings, Vol. 11, No.1, pp1-208.

Hawking, P. \& McCarthy, B. (2000), 'Industry collaboration: a practical approach for ERP education', ASCE '00 Proceedings of the Australian Conference on Computing Education, Melbourne, Australia, pp129-133.

Hergert, M. (2009), 'Student perceptions of the value of internships in business education', American Journal of Business Education, Vol. 2, No. 8, pp9-13.

Hogan, C. (2009), 'Making the most of visiting speakers (for everyone involved)', Training and Management Development Methods, Vol. 23, No. 3, pp371-383.

Holden, R. \& Hamblett, J. (2007), 'The transition from higher education into work: tales of cohesion and fragmentation', Education + Training, Vol. 49 No. 7, pp516-85.

Holdsworth, A., Watty, K., \& Davies, M. (2009). Developing capstone experiences. Melbourne: Centre for Study of Higher Education, University of Melbourne.

Houterman, B. (2009), Submission in regard to ASIC: 'Reviewing and updating RG146: Training financial product advisers', 10 August. Available at www.asic.gov.au. Accessed 10 July 2011.

Investopedia (2012), Definition of Applied Economics. Available at: http://www.investopedia.com/terms/a/applied-economics.asp\#axzz28aDbsaE7. Accessed 8 October 2012.

Jackling, B. \& Sullivan, C. (2007), 'Financial planners in Australia: an evaluation of gaps in technical and behavioural skills’, Financial Services Review, vol. 16, pp211-228. 
Jacobi, M. (1991), 'Mentoring and undergraduate academic success: a literature review', Review of Educational Research, Vol. 61, pp505-532. http://dx.doi.org/10.3102/00346543061004505

Jones, B. \& Iredale, N. (2010), 'Enterprise education as pedagogy', Education + Training, vol. 52, no. 1, pp7-19.

Knight, P. (2007). Fostering and assessing 'wicked’ competences. Milton Keynes, UK: Institute of Educational Technology, the Open University 2007. Available at http://www.open.ac.uk/cetl-workspace/cetlcontent/documents/460d1d1481d0f.pdf. Accessed 8 October 2012.

Kolb, D. A. (1984), Experiential Learning: Experience as the Source of Learning and Development, Prentice-Hall, New Jersey.

Lester, F.L. \& Cole, J.A. (2009), 'Using a financial trading room to facilitate an interdisciplinary learner-centered paradigm: one school's experience', Southwestern Business Administration Journal, Spring, pp44-57.

Mata, H., Latham, P. \& Ransome, Y. (2010), 'Benefits of professional organisation membership and participation in a national conference: considerations for students and new professionals', Health Promotion Practice, Vol. 11, No. 4, pp450-453. http://dx.doi.org/10.1177/1524839910370427

Nicol, D.J. \& Macfarlane-Dick, D. (2006), 'Formative assessment and self-regulated learning: a model and seven principles of good feedback practice', Studies in Higher Education. 31(2), pp199-218. http://dx.doi.org/10.1080/03075070600572090

Page, N., Neck, S. \& Wiseman, R.L. (1999), ‘College/university coordinators’ perceptions of quality indicators for co-op/internship sites', Journal of Cooperative Education, vol. 34, pp43-53.

Patrick, C., Peach, D, \& Pocknee, C. (2009), 'The WIL [Work Integrated Learning] Report: A national scoping study' [Australian Learning and Teaching Council (ALTC) Final Report]. Brisbane. Queensland University of Technology. Available at: altc.edu.au. Accessed: 11 November 2011.

Patton, W., and McMahon, M. (2001). Implementing career development learning programs. In W. Patton \& M. McMahon (Eds.), Career development programs, Preparation for lifelong career decision making, pp10-21. Melbourne: ACER Press.

Paul, P. \& Mukhopadhyay, K. (2005), 'Experiential learning in international business education’, Journal of Teaching in International Business, Vol. 16, No. 2, pp. 7-25. http://dx.doi.org/10.1300/J066v16n02_02

Phillips, C.R. \& Phillips, A.S. (2002), 'Helping business students bridge the gap with the real world'. Proceedings: Allied Academies International Conference, Vol. 7, No.1, pp6568.

Pool, L.D. \& Sewell, P. (2007), 'The key to employability: developing a practical model of graduate employability’, Education + Training, Vol. 49, Iss. 4, pp277-289.

Rae, D. (2007), 'Connecting enterprise and graduate employability', Education + Training, Vol. 49 No.8/9, pp605-619.

Rainsbury, E., Hodges, D., Burchell, N. \& Lay, M. (2002), 'Ranking workplace competencies: student and graduate perceptions', Asia-Pacific Journal of cooperative Education, Vol. 3, No. 2, pp8-18.

Rossetto, L.C, \& Murphy, B. (2010), 'Embedding communication skills for future financial planners’, Australasian Accounting, Business and Finance Journal, vol. 4, issue 4, pp73-85.

Rudman, R. (1995), Competencies and capabilities for effective human resource management. Paper presented at the $22^{\text {nd }}$ annual conference of the Asian Regional Training and Development Organization. Melbourne, Australia. 
Schlee, R. P. (2000), 'Mentoring and the professional development of business students', Journal of Management Education, Vol. 24, pp322-337. http://dx.doi.org/10.1177/105256290002400304

Schmidt, S.M.P., Ralph, D.L. \& Buskirk, B. (2008), 'The effective marketing class: enhancing student learning', Journal of American Academy of Business, Vol. 13, No. 2, pp 52-57.

Smith, P.A. (2001), 'Understanding self-regulated learning and its implications for accounting educators and researchers', Issues in Accounting Education, Vol. 16, No. 4, pp663-700.

Subramaniam, N. \& Freudenberg, B. (2007), 'Preparing accounting students for success in the professional environment: enhancing self-efficacy through a work integrated learning program', Asia-Pacific Journal of Cooperative Education, Vol. 8, No. 1, pp87-102.

Thornton, J. \& King, B. (2006), 'Educating for enterprise - the challenge for universities', Journal of Asia Entrepreneurship and Sustainability, vol. 11, no. 4, pp1-8.

van Rensburg, H. \& Danaher, P.A. (2009), 'Facilitating formative feedback: an undervalued dimension of assessing doctoral students’ learning', ATN Assessment Conference, RMIT University. Available at http://emedia.rmit.edu.au/conferences/index.php/ATNAC/ATNAC09/paper/viewFile/ 86/18. Accessed 5 October 2010.

von Treuer, K., Sturre, V., Keele, S. \& McLeod, J. (2011), 'An integrated model for the evaluation of work placements', Asia-Pacific Journal of Cooperative Education, Vol. 12, No. 3, pp195-204.

Weimer, M. (2002), Learner-centered teaching: five key changes to practice, Josey-Bass, San Francisco, CA.

Zorek, J.A., Katz, N.L. \& Popovich, N.G. (2011), 'Instructional design and assessment: guest speakers in a professional development seminar series', American Journal of Pharmaceutical Education, Vol. 75, No. 2, pp159-183. http://dx.doi.org/10.5688/ajpe75228 
AABFJ | Volume 7, no. 3, 2013 